\title{
Abundance of the reef-building Petaloconchus varians (Gastropoda: Vermetidae) on intertidal rocky shores at Ilha Grande Bay, southeastern Brazil
}

\author{
ANDRÉ BREVES ${ }^{1}$, MARIA TERESA M. DE SZÉCHY ${ }^{2}$, HELENA P. LAVRADO ${ }^{1}$ and ANDREA O.R. JUNQUEIRA ${ }^{1}$ \\ ${ }^{1}$ Laboratório de Benthos, Departamento de Biologia Marinha, Instituto de Biologia, Centro de Ciências da Saúde/CCS, \\ UFRJ, Avenida Carlos Chagas Filho, 373, Ilha do Fundão, Cidade Universitária, 21941-971 Rio de Janeiro, RJ, Brazil, \\ ${ }^{2}$ Laboratório Integrado de Ficologia, Departamento de Botânica, CCS, UFRJ, Avenida Carlos Chagas \\ Filho, 373, Ilha do Fundão, Cidade Universitária, 21941-971 Rio de Janeiro, RJ, Brazil
}

Manuscript received on July 11, 2016; accepted for publication on October 11, 2016

\begin{abstract}
The reef-building vermetid Petaloconchus varians occurs in the western Atlantic Ocean, from the Caribbean Sea to the southern coast of Brazil. The present study evaluated the abundance of $P$. varians on intertidal rocky shores in Ilha Grande Bay (Rio de Janeiro State), and characterized their reefs, describing the species density, besides the weight and the belt width of the reefs. Petaloconchus varians reefs were recorded at 25 sites, with rocky shores exposed to different wave action (very sheltered, sheltered, semi-exposed and exposed) and slopes $\left(10^{\circ}\right.$ to $\left.46^{\circ}\right)$. Clusters of individuals constructed large reefs along the middle intertidal zone, creating a wide belt ( $38 \mathrm{~cm}$ to $2 \mathrm{~m}$ ). The density of $P$. varians and the weight of the reefs ranged from 620 to 2,559 ind. $100 \mathrm{~cm}^{-2}$ and from 100 to $1,500 \mathrm{~g} .100 \mathrm{~cm}^{-2}$, respectively. Considering that the species was last reported from the area in the mid- $20^{\text {th }}$ century, the present study suggests that $P$. varians reefs are becoming dominant in the intertidal zone of rocky shores in Ilha Grande Bay. This is a contribution to knowledge of this ecosystem in Ilha Grande Bay, in view of local or global ecological changes.
\end{abstract}

Key words: abundance, molluscs, Rio de Janeiro, Southwestern Atlantic Ocean, wave exposure.

\section{INTRODUCTION}

The family Vermetidae comprises sessile marine gastropods with irregularly spiral shells that are attached on hard substrata. They are usually abundant in the intertidal zone, especially in the tropics (Keen 1961). One of the most interesting and remarkable aspects of the vermetids is their role as reef-builders (Safriel 1974, Vescogni et al. 2008, Colombo et al. 2013). They are among

Correspondence to: André Breves

E-mail: abrevesramos@gmail.com the most important bioconstructors in the marine environment (Chemello and Silenzi 2011).

Several vermetid species form monospecific clusters of tubes, which can reach a considerable size (Savazzi 1996). Among other important environmental features, wave action is commonly invoked to explain the development of vermetid reefs (Hughes 1979), their vertical distribution along the intertidal zone (Lipkin and Safriel 1971) and their densities (Schiaparelli and Cattaneo-Vietti 1999, Kelly III 2007). Antonioli et al. (1999) and Chemello and Silenzi (2011) stated that vermetid 
platforms are rare along sheltered coasts of the Mediterranean Sea, and concluded that wave action influences the distribution and size of the reef structures on a small spatial scale. Petaloconchus lilandikike Kelly, 2007, from Guam, Philippine Sea, builds compact colonies in exposed areas or occurs singly at more-sheltered sites (Kelly III 2007). In contrast, some species of the genus Petaloconchus prefer calm waters, according to Laborel (1977).

Vermetids are widely distributed in inshore and offshore waters along the Brazilian coast (Spotorno et al. 2012). They were recorded as the primary or secondary framework of reef communities of oceanic islands off Brazil, including the Abrolhos Archipelago (Leal 1991, Villaça and Pitombo 1997), Atol das Rocas (Soares-Gomes et al. 2001, Gherardi and Bosence 2001, Soares et al. 2011) and Fernando de Noronha Archipelago (Laborel and Kempf 1965, Matthews and Kempf 1970, Eston et al. 1986).

Fossil vermetids from the Holocene were reported as forming reefs above the present sea levels on the Brazilian coast (Laborel 1977). In the $19^{\text {th }}$ century, similar vermetid structures were recorded for the coast of Pernambuco State, as a "causeway" covered by living organisms (Darwin 1841). Later, Laborel and Kempf (1965) described the Brazilian vermetid reefs, recorded from São Roque Cape to Rio de Janeiro State, formed by Petaloconchus and Dendropoma species. Both vermetids grew on hard substrata, between the belts of the barnacle Tetraclita and the brown macroalga Sargassum, at different wave-exposure levels and independently of the substratum slope (Laborel and Kempf 1965). However, Laborel (1977) commented that the extensive vermetid formations described on the Brazilian coast by previous authors had decreased or completely disappeared from many locations, and no vermetid reefs were seen south of Cabo Frio, Rio de Janeiro State. A similar phenomenon of local extinction seems to have occurred in the Mediterranean Sea, where Petaloconchus was the major reef-building vermetid until the Holocene (Vescogni et al. 2008).

Petaloconchus varians (Orbigny 1841) was first described based on material collected at an unspecified locality in Rio de Janeiro State (syntype deposited in the National History Museum of the United Kingdom - NHMUK1854.12.4.553). In the western Atlantic Ocean, the species was recorded from the Caribbean Sea to Santa Catarina State in southern Brazil (Spotorno et al. 2012, Bieler 2015), including Brazilian oceanic islands (Eston et al. 1986, Soares et al. 2011). Although there is a record of $P$. varians for Ilha Grande Bay (on the southernmost coast of Rio de Janeiro State) dating from the end of the last century in the Mollusc Collection of the Museu Nacional / UFRJ [MNRJ 11869], the occurrence of vermetids was not recorded for rocky shores of Ilha Grande Bay (Haas 1953, Costa 1962) and nearby areas (northern coast of São Paulo State) (Nonato and Pérès 1961, Oliveira Filho and Mayal 1976) from the 1940s through the 1970s. Since the 2000s, conspicuous populations of $P$. varians have been recorded for some intertidal rocky shores in Ilha Grande Bay (Moysés et al. 2007, Breves-Ramos et al. 2010a, b, Ignacio et al. 2010); and Breves and Skinner (2014) reported the species on floating marine debris in this bay. Despite their importance along the Brazilian coast, ecological aspects of $P$. varians reefs have been little investigated.

The present contribution describes the abundance of $P$. varians in the intertidal zone of different rocky shores in Ilha Grande Bay, with estimates of the species' density and weight and the belt width of the reefs. The relationship between the abundance of vermetids and wave exposure was analyzed, in order to assess the importance of this environmental feature. 


\section{MATERIALS AND METHODS}

\section{STUDY AREA}

The study was carried out in Ilha Grande Bay, which lies partly in Angra dos Reis and partly in Paraty municipalities (Figure 1). The shores of this bay have undergone rapid urbanization, with increasing discharges of organic pollutants into the water (Alho et al. 2002). Potentially polluting enterprises are established around Angra dos Reis, including the Petrobras Oil Terminal (Jacuacanga Inlet), Brasfels shipyard and Angra dos Reis Port (Angra dos Reis Inlet), and Almirante Álvaro Alberto Nuclear Power Station (Ribeira Inlet) (Creed et al. 2007).

Ilha Grande Bay, with an area of around 3,100 $\mathrm{km}^{2}$, has many inlets and 365 islands of varying sizes. The local climate is tropical wet (Silva et al. 1989). According to Belo (2003), the geographical characteristics of the coastline of this bay facilitate the entry of waves from S-SE, with stronger wave action in the area of Mambucaba in the western portion of the bay. Rocky shores, formed mainly of igneous rocks with different slopes and roughness, are important ecosystems in the bay (Creed et al. 2007). Creed et al. (2007) described the physical and chemical characteristics of the seawater for more than 40 sites along the coastline of this bay and reported spatial variations in salinity, seawater surface temperature and nutrients related to mesoscale oceanographic events and local influences, such as pollution.

\section{FIELDWORK}

From April 2008 through December 2009, rocky shores at different sites in Ilha Grande Bay and surrounding areas were surveyed. Samples were taken at 25 sites where vermetid reefs were observed, mainly on islands, from Paraty Inlet to Jacuacanga Inlet, including Ilha Grande Island (Figure 1). The sampling effort was greater around

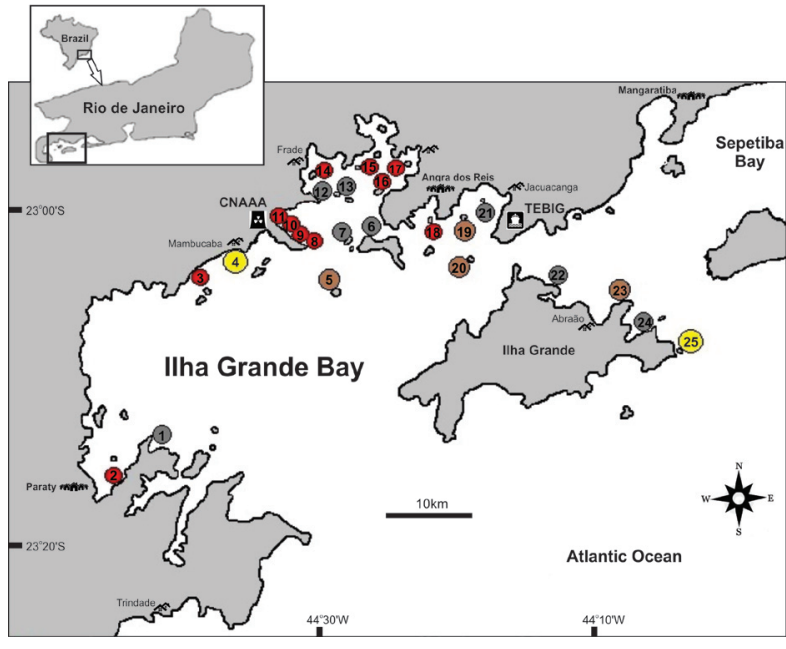

Figure 1 - Ilha Grande Bay and surrounding areas (Rio de Janeiro State, Brazil), indicating the 25 sampling sites where reefs of Petaloconchus varians occurred on intertidal rocky shores, classified by the wave-exposure level (red circle $=$ very sheltered, gray circle $=$ sheltered, brown circle $=$ semi-exposed, yellow circle $=$ exposed). CNAAA $=$ Almirante Álvaro Alberto Nuclear Power Station; TEBIG = Petrobras Oil Terminal.

Angra dos Reis city since there is a record of $P$. varians close to this area dating from the end of the last century.

At each sampling site, during low tides, a line about $15 \mathrm{~m}$ long was laid over the vermetid belt, parallel to the waterline. Inside the area delimited by this line, the slope of the rocky shore was measured with a clinometer along the intertidal zone, and the vertical length of the reef belt (belt width) was measured with a tape at five different points. Five quadrats of $100 \mathrm{~cm}^{2}$ were randomly positioned along the line, to evaluate the abundance of the vermetids in terms of density and weight. The surface layer of the reef delimited by each quadrat area was photographed with a digital camera, to estimate the density of living vermetids; then, the reef blocks inside each quadrat were scraped for evaluated their weight. The material from each quadrat was placed in plastic bags, fixed in $70 \%$ ethanol and transported to the laboratory. 


\section{TREATMENT OF THE SAMPLES}

The vermetids were identified on the basis of morphological analysis of the shells. The specimens were compared with published descriptions (Keen 1961, Strong 2003, Weinberger et al. 2010, Soares et al. 2011), especially descriptions and illustrations of species of Petaloconchus from Rio de Janeiro State (Orbigny 1841, Absalão and Rios 1987). They were also compared with material deposited in the malacological collections of the Museu Nacional, Universidade Federal do Rio de Janeiro (UFRJ); Instituto de Biologia, UFRJ; and Museu de Zoologia da Universidade de São Paulo (MZUSP). Shell morphologies were observed in a scanning electron microscope. The shells were then photographed and deposited in the Malacological Collection of the Museu Nacional, UFRJ [MNRJ 19147-19171].

The vermetid densities were estimated by counting the shell apertures (Schiaparelli et al. 2003) from the digital photographs, using the software Corel Photo-Paint 9, according to Spotorno (2007). Densities were estimated for 15 sites $(3,4,5,7,8,9,10,13,14,15,17,18,19$, 20 and 21) since masses of macroalgae and sessile invertebrates covered the vermetid apertures at the other 10 sites (1, 2, 6, 11, 12, 16, 22, 23, 24 and 25).

Five reef blocks from each site were air-dried for about $1 \mathrm{~h}$ and weighed on a digital balance in order to estimate the weight of the vermetid reefs.

\section{DATA ANALYSES}

The degree of wave exposure at each site was estimated indirectly from the wave fetch, according to Burrows et al. (2008), who considered wave fetch to be an ideal tool for classifying and mapping coastal habitats. To determine the average wave fetch, we positioned a circle of 16 sectors of $22.5^{\circ}$ over a map of each site, using the software ARCGIS 10 , and measured the distances from the site to the free margins (no land masses) of each sector.
According to the average wave fetch, the sites were then classified in four levels of wave exposure: 1 - very sheltered $(<2.01 \mathrm{~km}) ; 2$ - sheltered $(2.01$ to $6.00 \mathrm{~km}) ; 3$ - semi-exposed (6.01 to $18.00 \mathrm{~km}$ ); and 4 - exposed (>18.00 km).

The density and weight of the vermetid reefs were described for each site by median, 25\%-75\% interquartile and non-outlier values. Statistical comparisons of these variables among different wave-exposure levels were not possible, because of the non-homogeneity of variances as confirmed by the Levene Test, as well as the different sample sizes.

Spearman correlation analysis was performed using the software GraphPad Prism 5.0 to assess the potential effect of wave exposure (average wave fetch) on the vermetid density and on the weight and the belt width of the reefs, using the median values of these variables for each site $(n=25)$. Spearman correlation analyses were also performed between between the belt width of the reefs and the slope of the rocky shores $(n=125)$.

\section{RESULTS}

Based on the external and internal morphological characteristics of the shells, we determined that all the vermetid reefs from Ilha Grande Bay were monospecific, constructed by Petaloconchus varians. The specimens from the bay showed a similar architecture to those described by Orbigny (1841) (Figure 2a, b). The shells were colored violet to dark brown, and usually had strong external ribs (Figure 2c) and internal lamellas in the middle of the teleoconch (Figure 2d)

Petaloconchus varians reefs were recorded from the inner to outer areas of Ilha Grande Bay, at sites subject to different wave-exposure levels and rocky-shore slopes, varying, on average, from around $10^{\circ}$ at site 4 to around $46^{\circ}$ at site 11 (Table I). 


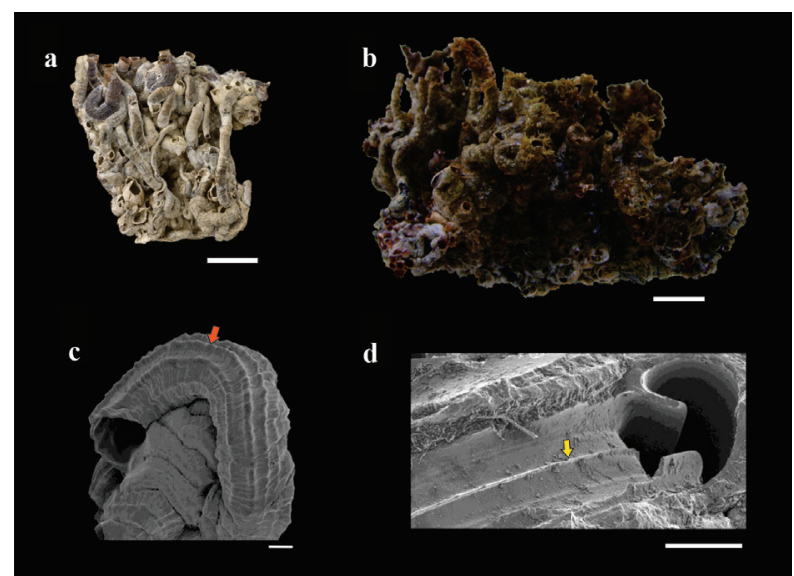

Figure 2 - Petaloconchus varians (d'Orbigny, 1841): (a) Syntype (NHMUK 1854.12.4.553) - photograph of the lateral view (scale bar $=2 \mathrm{~cm}$ ); (b-d) From Ilha Grande Bay: (B) A reef sample in lateral view (scale bar $=2 \mathrm{~cm}$ ); (c-d) Details of the shells examined by scanning electron microscopy; (c) Prominent longitudinal ribs on the last whorls of the teleoconch (red arrow); (d) Internal lamella on the early whorls of the teleoconch (yellow arrow) (scale bar $=1 \mathrm{~mm}$ ).

The vermetids were the dominant sessile organisms in the middle intertidal zone of the rocky shores, generally forming a conspicuous and continuous belt similar to a bicycle lane (Figure 3a, b). At some sites, for example those at Ilha Grande Island (sites 22 to 25 ), the vermetids were distributed

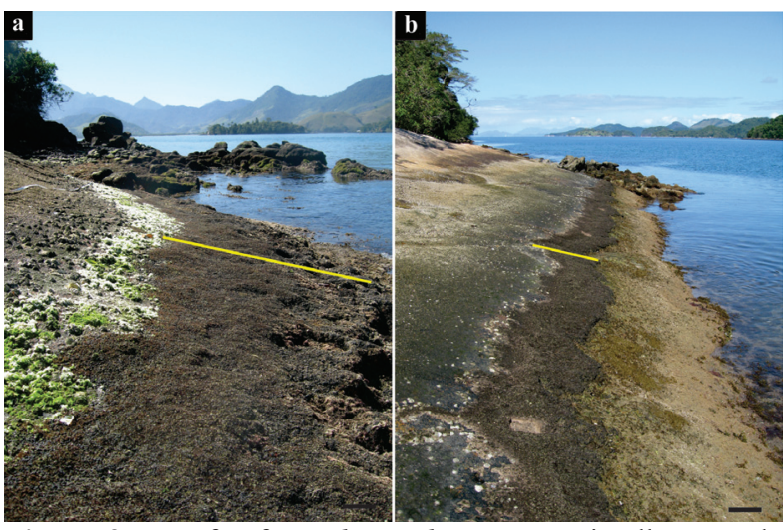

Figure 3 - Reefs of Petaloconchus varians in Ilha Grande Bay (yellow bar), forming a continuous belt along the middle intertidal rocky shore: (a) site 17; (b) site 15 (scale bar $=10$ $\mathrm{cm})$.

in patches, mixed with other sessile organisms such as barnacles and calcareous algae that extended above or below the middle portion.

Petaloconchus varians reefs formed large clusters of shells, creating microhabitats (Figure 4a). The reefs have a rigid structure, arranged in no clear pattern, but with a lower layer of dead individuals and an upper layer of living individuals (Figure 4b).

The belt width varied, on average, from $38 \mathrm{~cm}$ (site 3) to around $2 \mathrm{~m}$ (site 21) (Table I). The largest

TABLE I

Sites in Ilha Grande Bay where reefs of Petaloconchus varians occurred: their geographical coordinates, fetch, waveexposure classification, slope of the rocky shore and belt width. Arithmetic means and standard deviation (in parentheses).

\begin{tabular}{|c|c|c|c|c|c|c|}
\hline Site & Local name & Coordinates & Fetch $(\mathrm{Km})$ & Exposure level & Slope $\left({ }^{0}\right)$ & $\begin{array}{c}\text { Band } \\
\text { width } \\
\text { (cm) }\end{array}$ \\
\hline 1 & Praia Vermelha & $23^{\circ} 11^{\prime} 22.10^{\prime \prime} \mathrm{S} / 44^{\circ} 38^{\prime} 38.24^{\prime \prime} \mathrm{W}$ & $5.17(9.63)$ & Sheltered & $\begin{array}{l}21.20 \\
(1.79)\end{array}$ & $\begin{array}{c}76.80 \\
(12.95)\end{array}$ \\
\hline 2 & $\begin{array}{l}\text { Enseada do Bom } \\
\text { Jardim }\end{array}$ & $23^{\circ} 13^{\prime} 13.35^{\prime \prime} \mathrm{S} / 44^{\circ} 40^{\prime} 46.74^{\prime \prime} \mathrm{W}$ & $1.13(1.51)$ & Very-sheltered & $\begin{array}{l}18.00 \\
(1.41)\end{array}$ & $\begin{array}{l}79.00 \\
(11.67)\end{array}$ \\
\hline 3 & São Gonçalinho & $23^{\circ} 3^{\prime} 4.80^{\prime \prime} \mathrm{S} / 44^{\circ} 36^{\prime} 48.85^{\prime \prime} \mathrm{W}$ & $1.05(1.87)$ & Very-sheltered & $\begin{array}{l}23.00 \\
(11.20)\end{array}$ & $\begin{array}{c}38.40 \\
(19.11)\end{array}$ \\
\hline 4 & Praia dos Coqueiros & $23^{\circ} 2^{\prime} 14.89^{\prime \prime} \mathrm{S} / 44^{\circ} 33^{\prime} 15.31^{\prime \prime} \mathrm{W}$ & $18.36(49.62)$ & Exposed & $\begin{array}{l}9.80 \\
(2.05)\end{array}$ & $\begin{array}{l}135.60 \\
(11.76)\end{array}$ \\
\hline 5 & Ilha de Búzios & $23^{\circ} 3{ }^{\prime} 27.59^{\prime \prime} \mathrm{S} / 44^{\circ} 25^{\prime} 2.89^{\prime \prime} \mathrm{W}$ & $6.29(10.07)$ & Semi-exposed & $\begin{array}{l}23.90 \\
(6.90)\end{array}$ & $\begin{array}{l}73.40 \\
(26.79)\end{array}$ \\
\hline 6 & Ponta Escalvada & $23^{\circ} 1^{\prime} 52.5^{\prime \prime} \mathrm{S} / 44^{\circ} 22^{\prime} 39.4^{\prime \prime} \mathrm{W}$ & $4.94(8.79)$ & Sheltered & $\begin{array}{l}20.03 \\
(3.28)\end{array}$ & $\begin{array}{l}73.00 \\
(26.83)\end{array}$ \\
\hline 7 & Ilha do Brandão & $23^{\circ} 1^{\prime} 34.12^{\prime \prime} \mathrm{S} / 44^{\circ} 24^{\prime} 1.32^{\prime \prime} \mathrm{W}$ & $5.63(10.22)$ & Sheltered & $\begin{array}{l}25.20 \\
(5.40)\end{array}$ & $\begin{array}{c}87.80 \\
(28.80)\end{array}$ \\
\hline
\end{tabular}


TABLE I (continuation)

\begin{tabular}{|c|c|c|c|c|c|c|}
\hline Site & Local name & Coordinates & Fetch $(\mathrm{Km})$ & Exposure level & Slope $\left(^{\circ}\right)$ & $\begin{array}{c}\text { Band } \\
\text { width } \\
(\mathrm{cm})\end{array}$ \\
\hline 8 & Ponta da Pitanga & $23^{\circ} 01^{\prime} 4.91^{\prime \prime} \mathrm{S} / 44^{\circ} 26^{\prime} 8.34^{\prime \prime} \mathrm{W}$ & $0.45(0.62)$ & Very-sheltered & $\begin{array}{l}19.60 \\
(5.55)\end{array}$ & $\begin{array}{l}83.40 \\
(25.45)\end{array}$ \\
\hline 9 & Marina Piraquara & $23^{\circ} 00^{\prime} 59.8^{\prime \prime} \mathrm{S} / 44^{\circ} 26^{\prime} 26.3 \mathrm{~W}$ & $1.39(2.51)$ & Very-sheltered & $\begin{array}{l}24.80 \\
(3.03)\end{array}$ & $\begin{array}{l}83.80 \\
(26.33)\end{array}$ \\
\hline 10 & Ponta do Arame & $23^{\circ} 00^{\prime} 49.66^{\prime \prime} \mathrm{S} / 44^{\circ} 26^{\prime} 39.22^{\prime \prime} \mathrm{W}$ & $1.54(3.06)$ & Very-sheltered & $\begin{array}{l}13.15 \\
(1.65)\end{array}$ & $\begin{array}{l}123.00 \\
(34.21)\end{array}$ \\
\hline 11 & Praia de Piraquara & $23^{\circ} 00^{\prime} 41.7^{\prime \prime} \mathrm{S} / 44^{\circ} 26^{\prime} 45.6^{\prime \prime} \mathrm{W}$ & $1.26(2.34)$ & Very-sheltered & $\begin{array}{l}46.20 \\
(9.76)\end{array}$ & $\begin{array}{l}141.20 \\
(37.91)\end{array}$ \\
\hline 12 & Ponta da Fortaleza & $22^{\circ} 59^{\prime} 41.8^{\prime \prime} \mathrm{S} / 44^{\circ} 25^{\prime} 42.6^{\prime \prime} \mathrm{W}$ & $2.22(3.05)$ & Sheltered & $\begin{array}{l}24.80 \\
(4.15)\end{array}$ & $\begin{array}{l}69.20 \\
(10.71)\end{array}$ \\
\hline 13 & Ilha Itanhangá & $22^{\circ} 59^{\prime} 23.7^{\prime \prime} \mathrm{S} / 44^{\circ} 24^{\prime} 32.1^{\prime \prime} \mathrm{W}$ & $3.93(9.09)$ & Sheltered & $\begin{array}{l}16.99 \\
(6.23)\end{array}$ & $\begin{array}{l}132.80 \\
(53.08)\end{array}$ \\
\hline 14 & $\begin{array}{c}\text { Ilha Cunhambebe } \\
\text { Grande }\end{array}$ & $22^{\circ} 58^{\prime} 4.4^{\prime \prime S} / 44^{\circ} 24^{\prime} 52.4^{\prime \prime} \mathrm{W}$ & $1.08(1.26)$ & Very-sheltered & $\begin{array}{l}29.80 \\
(6.94)\end{array}$ & $\begin{array}{l}131.00 \\
(23.75)\end{array}$ \\
\hline 15 & Ilha do Aleijado & $22^{\circ} 57^{\prime} 58.9^{\prime \prime} \mathrm{S} 44^{\circ} 22^{\prime} 06.0^{\prime \prime} \mathrm{W}$ & $0.78(1.19)$ & Very-sheltered & $\begin{array}{l}14.60 \\
(4.88)\end{array}$ & $\begin{array}{c}92.20 \\
(17.53)\end{array}$ \\
\hline 16 & Ilha dos Coqueiros & $22^{\circ} 59^{\prime} 7.2^{\prime \prime} \mathrm{S} / 44^{\circ} 21^{\prime} 15.7^{\prime \prime} \mathrm{W}$ & $1.06(1.18)$ & Very-sheltered & $\begin{array}{l}16.80 \\
(3.56)\end{array}$ & $\begin{array}{l}141.00 \\
(55.83)\end{array}$ \\
\hline 17 & Ilha do Capítulo & $22^{\circ} 58^{\prime} 46^{\prime \prime} \mathrm{S} / 44^{\circ} 20^{\prime} 27.7^{\prime \prime} \mathrm{W}$ & $1.05(1.13)$ & Very-sheltered & $\begin{array}{l}10.47 \\
(6.42)\end{array}$ & $\begin{array}{l}137.60 \\
(50.29)\end{array}$ \\
\hline 18 & Ilha do Calombo & $23^{\circ} 01^{\prime} 35.6^{\prime \prime} \mathrm{S} / 44^{\circ} 18^{\prime} 33.2^{\prime \prime} \mathrm{W}$ & $0.79(0.93)$ & Very-sheltered & $\begin{array}{l}17.00 \\
(4.80)\end{array}$ & $\begin{array}{l}46.00 \\
(4.18)\end{array}$ \\
\hline 19 & Ilha do Peregrino & $23^{\circ} 1^{\prime} 36.13^{\prime \prime} \mathrm{S} / 44^{\circ} 17^{\prime} 8.09^{\prime \prime} \mathrm{W}$ & $6.38(9.45)$ & Semi-exposed & $\begin{array}{l}20.80 \\
(2.28)\end{array}$ & $\begin{array}{c}68.40 \\
(36.06)\end{array}$ \\
\hline 20 & Ilha Saracura & $23^{\circ} 03^{\prime} 15.3^{\prime \prime} \mathrm{S} / 44^{\circ} 16^{\prime} 10.0^{\prime \prime} \mathrm{W}$ & $7.95(14.10)$ & Semi-exposed & $\begin{array}{l}19.32 \\
(8.81)\end{array}$ & $\begin{array}{l}111.40 \\
(83.24)\end{array}$ \\
\hline 21 & Ilha do Cavaco & $23^{\circ} 0 ’ 49.90^{\prime \prime} \mathrm{S} / 44^{\circ} 16^{\prime} 2.84^{\prime \prime} \mathrm{W}$ & $3.06(4.59)$ & Sheltered & $\begin{array}{l}12.80 \\
(5.62)\end{array}$ & $\begin{array}{l}198.60 \\
(46.52)\end{array}$ \\
\hline 22 & Praia do Japariz & $23^{\circ} 6^{\prime} 8.87^{\prime \prime} \mathrm{S} / 44^{\circ} 11^{\prime} 27.61^{\prime \prime} \mathrm{W}$ & $5.46(8.42)$ & Sheltered & $\begin{array}{l}33.10 \\
(6.75)\end{array}$ & $\begin{array}{c}75.00 \\
(17.68)\end{array}$ \\
\hline 23 & Praia do Morcego & $23^{\circ} 7^{\prime} 49.95^{\prime \prime} \mathrm{S} / 44^{\circ} 8^{\prime} 58.03^{\prime \prime} \mathrm{W}$ & $7.66(11.65)$ & Semi-exposed & $\begin{array}{l}25.40 \\
(4.62)\end{array}$ & $\begin{array}{l}100.00 \\
(18.71)\end{array}$ \\
\hline 24 & Enseada de Palmas & $23^{\circ} 9^{\prime} 4.40^{\prime \prime} \mathrm{S} / 44^{\circ} 7^{\prime} 9.56^{\prime \prime} \mathrm{W}$ & $2.49(6.05)$ & Sheltered & $\begin{array}{l}30.80 \\
(2.28)\end{array}$ & $\begin{array}{l}70.00 \\
(12.25)\end{array}$ \\
\hline 25 & Lage do Guriri & $23^{\circ} 10^{\prime} 24.26^{\prime \prime S} / 44^{\circ} 5^{\prime} 33.33^{\prime \prime} \mathrm{W}$ & $26.82(68.19)$ & Exposed & $\begin{array}{l}15.20 \\
(1.48)\end{array}$ & $\begin{array}{l}179.00 \\
(21.91)\end{array}$ \\
\hline
\end{tabular}

belt width $(2.57 \mathrm{~m})$ was observed on site 20 . Belt width and slope of the rocky shore were negatively correlated $(\mathrm{n}=125 ; \mathrm{r}=-0.35 ; \mathrm{p}<0.05)$ (Figure 5). However, the vermetid belt was relatively wide, on average $(141 \mathrm{~cm})$, on the steep rocky $\left(46.2^{\circ}\right)$ at site 11 . There was no significant correlation between the belt width and wave exposure $(n=25 ; r=0.08 ; p>0.05)$.
The density of $P$. varians varied from 412 individuals per quadrat at site 13 to 2,753 individuals at site 15 (Figure 6). Including outlying values, the maximum density occurred at site 19 , with 3,565 individuals per $100 \mathrm{~cm}^{2}$. The $P$. varians density varied differently among the sites (Figure 6), with low variability at sites 4 and 20 and high variability 


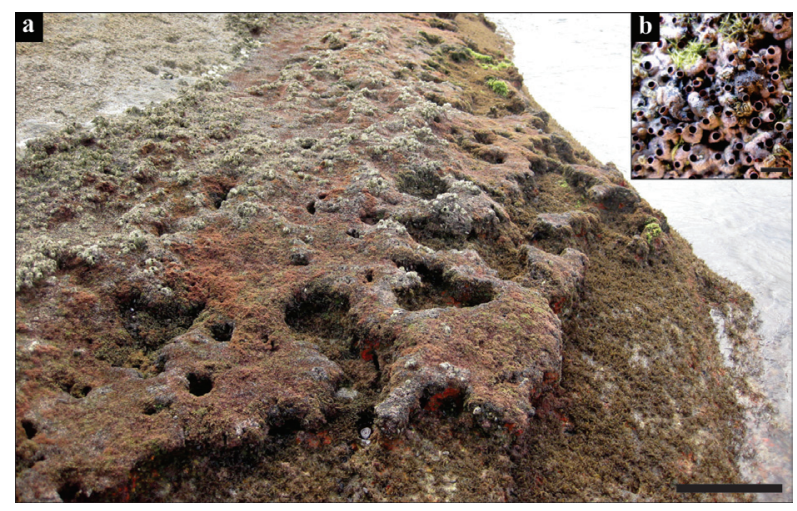

Figure 4 - Reefs of Petaloconchus varians (a) Bonfim Island (photograph by Andrea Junqueira) in Ilha Grande Bay (scale bar- $=-10 \mathrm{~cm}$ ); (b) Surface layer of the reef with the shell apertures (scale bar-=10 $\mathrm{mm}$ ).

at sites 3 and 13 (Figure 6). The variability was especially high at very sheltered and sheltered sites (levels 1 and 2) (Figure 7). There was no significant correlation between $P$. varians density and wave exposure $(n=15 ; r=-0.10 ; p>0.05)$.

The reef weight varied from $101 \mathrm{~g}$ per quadrat at site 2 to $1,495 \mathrm{~g}$ at site 17 . The weight was also highly variable among quadrats at each site and among sites (Figure 8). When the sites were grouped by the level of wave exposure, the weight was also highly variable (Figure 9). No significant correlations were found between the reef weight and wave exposure $(n=25 ; r=-0.03 ; p>0.05)$.

\section{DISCUSSION}

The individuals of Petaloconchus varians that constructed the monospecific reefs on the rocky shores of Ilha Grande Bay are morphologically similar to descriptions and morphological observations of this species provided in previous records for Rio de Janeiro State (Orbigny 1841, Breves-Ramos et al. 2010a, b, Breves and Skinner 2014), Atol das Rocas (Soares et al. 2011), Venezuela (Weinberger et al. 2010) and Florida, USA (Strong 2003).

The dominance of $P$. varians in the intertidal zone, as described here for many rocky shores

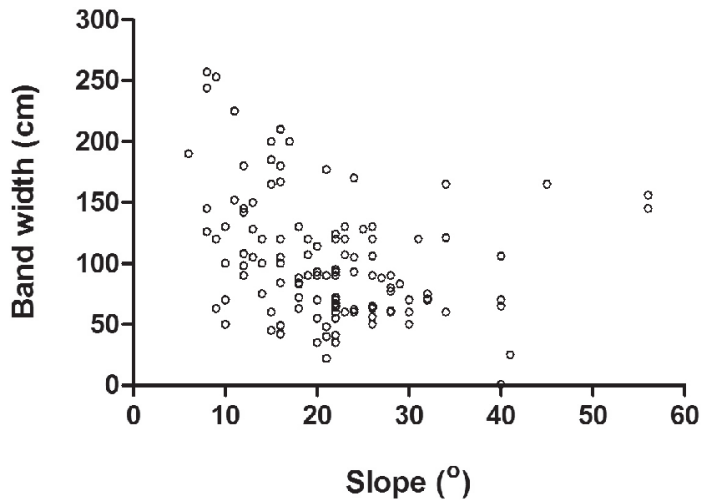

Figure 5-Relationship between the belt width of Petaloconchus varians reefs and the slope of the rocky shore $(n=125)$.

of Ilha Grande Bay, does not occur in some surrounding areas outside the bay, such as Trindade on the southwestern coast of Rio de Janeiro State, and Sepetiba Bay northeast of Ilha Grande Bay (personal observation). The absence of $P$. varians has recently been noted for other localities along the coast of Rio de Janeiro State. Ignacio et al. (2012) also observed no living vermetid reefs in Sepetiba Bay $\left(22^{\circ} 53^{\prime}\right.$ to $23^{\circ} 05^{\prime} \mathrm{S}, 043^{\circ} 35^{\prime}$ to $044^{\circ} 03^{\prime} \mathrm{W}$ ), a highly impacted, semi-confined water body adjacent to Ilha Grande Bay or in Arraial do Cabo $\left(22^{\circ} 57^{\prime}\right.$ to $23^{\circ} 00^{\prime} \mathrm{S}, 041^{\circ} 59^{\prime}$ to $\left.042^{\circ} 01^{\prime} \mathrm{W}\right)$, an area subject to upwelling events. It is likely that Ilha Grande Bay has some peculiar characteristics, still not fully evaluated, that affect the growth of $P$. varians,

In Ilha Grande Bay, P. varians reefs were found at sites close to urban centers where there is no sewage treatment, such as site 2 near Paraty city, site 14 near Frade village, site 17 near Japuíba inlet and site 18 near Angra dos Reis city (see Figure 1). These reefs are probably growing in seawater with high organic matter and turbidity. They were also present near the continental freshwater output from the Paraty Açu (site 2), São Gonçalo (site 3), Grataú and Bracuhy (site 14) and Japuíba (site 17) rivers, under variable conditions of salinity; and 


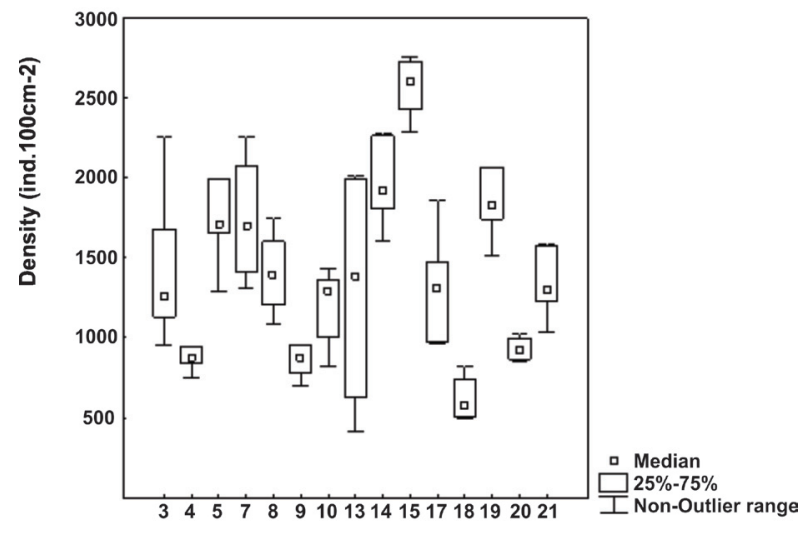

Figure 6 - Median, 25 - 75\% inter-quartile and non-outlier range values of Petaloconchus varians density at 15 sites in Ilha Grande Bay.

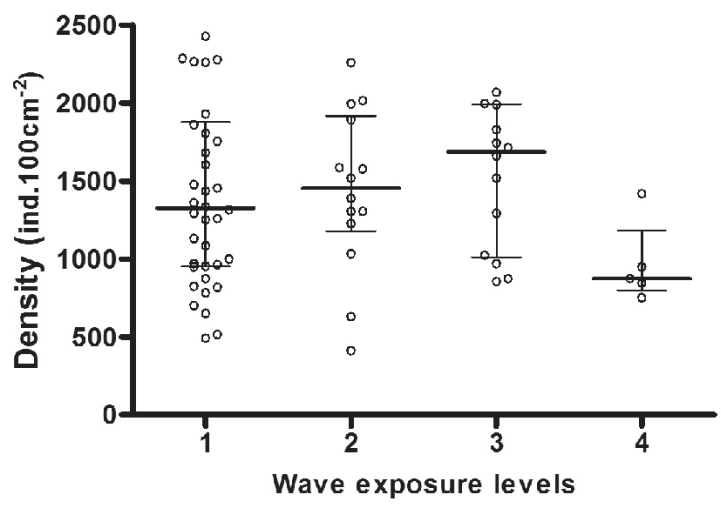

Figure 7 - Density of Petaloconchus varians in quadrats sampled at 15 sites with different wave-exposure levels in Ilha Grande Bay $(1=$ very-sheltered, 2 = sheltered, $3=$ semiexposed, 4 = exposed).

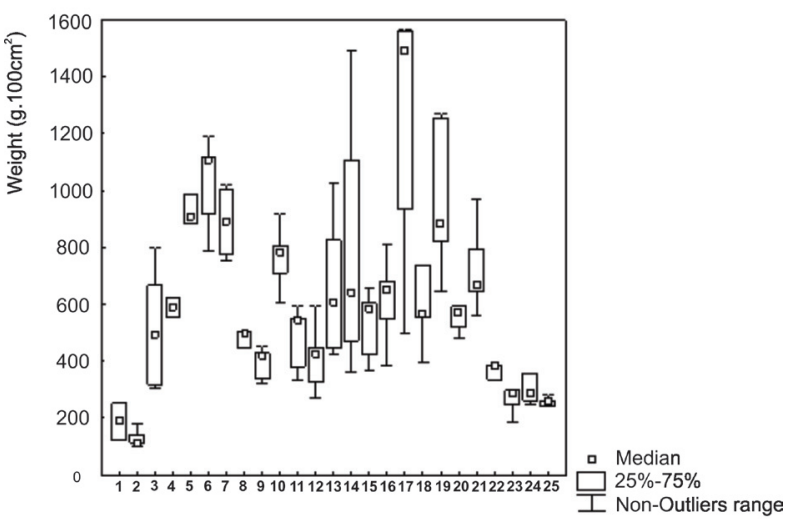

Figure 8 - Median, 25 - 75\% inter-quartile and non-outlier range values of the weight of Petaloconchus varians reefs at 25 sites in Ilha Grande Bay.

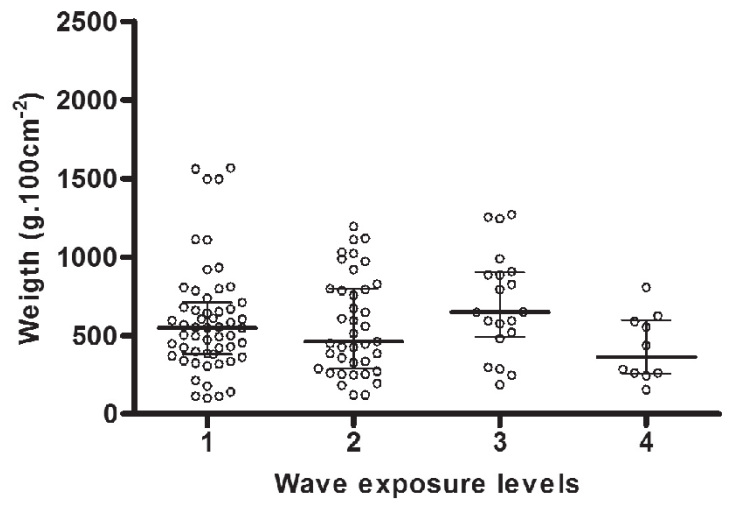

Figure 9 - Weight of Petaloconchus varians reefs in quadrats sampled at 25 sites with different wave-exposure levels in Ilha Grande Bay $(1$ = very sheltered, $2=$ sheltered, $3=$ semiexposed, 4 = exposed).

near the effluent discharge from the nuclear power plant (sites 8, 9, 10 and 11), where surface seawater temperature can reach $36^{\circ} \mathrm{C}$ (Teixeira et al. 2009). The occurrence of $P$. varians reefs in these widely varying environmental conditions confirms that the vermetids are highly tolerant of adverse conditions, such as low water quality, as described for other species and regions (Schiaparelli and CattaneoVietti 1999, Strathmann and Strathmann 2006, Vescogni et al. 2008). On the other hand, Calvo et al. (1998) suggested that species of Vermetidae live in zones free of pollution and with low rates of sedimentation, while Di Franco et al. (2011) showed that vermetids are negatively affected by marinas where contaminants accumulate.

The wave exposure of the rocky shores seems not to be a limiting factor for the presence of $P$. varians reefs in Ilha Grande Bay, since they were found from very sheltered to exposed sites. The lack of significant correlations between the wave fetch and the density or weight of $P$. varians reefs suggests that wave action does not affect the abundance of this species in the study area, although it does show a trend towards lower density at the exposed sites. This result contrasts with other studies (Schiaparelli and Cattaneo-Vietti 1999, Kelly III 
2007, Vescogni et al. 2008). Laborel (1977), for instance, concluded that $P$. varians from the South Atlantic prefers relatively calm waters. However, Azzopardi and Schembri (1997), who analyzed the influence of wave exposure, using the method of Thomas (1986), on the abundance of Dendropoma petraeum (Monterosato, 1884) from the Maltese Islands (Mediterranean Sea), found a significant positive correlation between the population density of juveniles and the exposure index. The lack of a significant correlation between the wave fetch and the belt width of the $P$. varians reefs suggests that wave action does not affect the distribution of this species along the intertidal. However, Franzitta et al. (2016) found a significant relationship between the width of the Dendropoma cristatum reef and the exposure index in the Mediteranea Sea. The index used in the present study may be less sensitive at a small scale. Further, experimental studies are needed to answer the questions about the influence of wave exposure on the abundance of vermetids.

In Ilha Grande Bay, steeper slopes of the rocky shore were related to decreasing belt widths of $P$. varians reefs, as indicated by the Spearman correlation analysis. In the Mediterranean Sea, athough the geological substrata are different from Ilha Grande Bay, slope also plays a role in determining the size and shape of bioconstructions (Azzopardi and Schembri 1997, Chemello and Silenzi 2011, Balistreri et al. 2015), with larger vermetid reefs developing where the slopes ranged between $15^{\circ}$ and $40^{\circ}$. Where slopes exceeded $40^{\circ}$, reefs rapidly decreased in size, and were absent from slopes exceeding $50^{\circ}$ (Chemello and Silenzi 2011). Curiously, Laborel and Kempf (1965) stated that the Brazilian vermetids seemed to be indifferent to the slope of the substratum.

The vermetid reefs modified the general zonation pattern previously described for the rocky shores of Ilha Grande Bay (Costa 1962) and surrounding areas (Nonato and Pérès 1961, Oliveira Filho and Mayal 1976), where the upper and middle intertidal zones had been dominated by barnacles. The vertical displacement of the vermetid reefs on the rocky shores of this bay agrees with the observations of Laborel and Kempf (1965) and Laborel (1977), who described these reefs for the intertidal zone, between the Tetraclita and Sargassum belts.

Because of the dense and complex aggregations of their tubes in a multi-layer structure, $P$. varians reefs increased the spatial complexity by creating microhabitats that provide shelter for many other marine invertebrates, as a bioengineer species (Colombo et al. 2013). In general, reef-builders form ecosystems that are extremely important in terms of biological resources (Cocito 2004), with incomparable diversification and a gene bank of vital importance (Villaça 2009). The $P$. varians reefs in Ilha Grande Bay are known to be a habitat for the invasive bivalves Isognomon bicolor (C.B. Adams, 1845) (Breves-Ramos et al. 2010a) and Myoforceps aristatus (Dillwyn, 1817) (BrevesRamos et al. 2010b). New studies should examine the importance of $P$. varians reefs for the local biodiversity and their ecological relationships with other species.

The extremely high densities of $P$. varians described for some sites in Ilha Grande Bay are comparable to those described for Bahía Concha, Colombia (Almanza et al. 2004), and are much higher than those described for Atol das Rocas, where this species was occasionally found (Soares et al. 2010). In other Brazilian regions, other vermetid species do not reach densities as high as those recorded for P. varians in Ilha Grande Bay, for example Dendropoma irregulare (d'Orbigny, 1842) from São Pedro and São Paulo Archipelago (Spotorno 2007). Although effective for counting living individuals, the photoquadrat technique may underestimate values because of epibionts present and also because other live and dead vermetid individuals may be located below the upper layer of the reefs. Since our study was a baseline, the 
weight was included as an additional variable for estimating the abundance of vermetid reefs through a three-dimensional representation of growth. On the other hand, for monitoring studies we recommend that destructive samplings not be conducted. Furthermore, vermetid reefs should be protected by specific regional Brazilian laws and regulations.

The disappearance of $P$. varians reefs from the Brazilian coast in the past (Laborel and Kempf 1965, Laborel 1977) and their current abundance and distribution on rocky shores, as described here for Ilha Grande Bay, should be better analysed in view of potential environmental changes, on local and global scales. Since vermetids are usually taken as a potential bioindicator for global changes, particularly rising sea levels, surface seawater temperatures (Silenzi et al. 2004, Chemello and Silenzi 2011) and ocean acidification (Milazzo et al. 2014), we recommend the implementation of integrated network studies with $P$. varians in Ilha Grande Bay, based mainly on the relationship of their abundance to physico-chemical drivers including salinity, temperature, nutrients and $\mathrm{pH}$.

\section{ACKNOWLEDGMENTS}

We would like to thank Conselho Nacional de Desenvolvimento Científico e Tecnológico (CNPq) for the $\mathrm{PhD}$ scholarship granted to the first author; to Eletronuclear Eletrobrás, Parque Estadual da Ilha Grande and Área de Proteção Ambiental do Cairuçu for logistical support; Fundação de Amparo à Pesquisa do Estado do Rio de Janeiro (FAPERJ) for funding the Project "Comunidades epilíticas fotófilas como indicadoras ambientais para a Baía da Ilha Grande, especialmente para a área de influência da Central Nuclear Almirante Álvaro Alberto (CNAAA)"; Instituto Estadual do Ambiente (INEA) for the authorization permit $\mathrm{N}^{\circ} 050 / 2012$ and Instituto Chico Mendes de Conservação da Biodiversidade (ICMBio) for the authorization permit $\mathrm{N}^{\circ} 17982-2$. We also thank the staff of Setor de Malacologia/MN, Laboratório de Benthos/UFRJ and Laboratório Integrado de Ficologia/UFRJ for helping in field work; Janet W. Reid for the English revision and the anonymous reviewers for critically reviewing and contributing to the manuscript.

\section{REFERENCES}

ABSALÃO RS AND RIOS EC. 1987. Petaloconchus myrakeenae, a new species of Vermetidae from Brazilian waters (Mollusca: Gastropoda). Braz J Biol 47(3): 415418.

ALHO CJR, SCHNEIDER M AND VASCONCELOS LA. 2002. Degree of threat to the biological diversity in the Ilha Grande State Park (RJ) and guidelines for conservation. Braz J Biol 62(3): 375-385.

ALMANZA L, BOLÍVAR F, BORRERO S, CAIAFA I, SALAS K, LUQUE MG AND VALDELAMAR JC. 2004. Estudio preliminar de la comunidad macrobentônica del mesolitoral rocoso de Bahía Concha (Parque Nacional Natural Tayrona, Magdalena, Colombia) em agosto de 2002. Acta Biol Col 9(1): 3-9.

ANTONIOLI F, CHEMELLO R, IMPROTA S AND RIGGIO S. 1999. Dendropoma lower intertidal reef formations and their palaeoclimatological significance, NW Sicily. Mar Geol 161: 155-170.

AZZOPARDI L AND SCHEMBRI PJ. 1997. Vermetid crusts from the Maltese Islands (Central Mediterranean). Mar Life 7(1-2): 7-16.

BALISTRERI P, CHEMELLO R AND MANNINO AM. 2015. First assessment of the vermetid reefs along the coasts of Favignana Island (Southern Tyrrhenian Sea). Biod J 6(1): 371-376.

BELO WC. 2003. O fundo marinho da Baía da Ilha Grande, RJ: evidências da ação de correntes e de ondas no canal central com base em formas de fundo observadas em registros de sonar (100KHz). Braz J Geophys 20(1): 17-30.

BIELER R. 2015. Petaloconchus varians (d'Orbigny 1839). In: MolluscaBase 2015. Accessed through: World Register of Marine Species at http://www.marinespecies.org/aphia. php $p=$ taxdetails\&id $=419554$ (accessed on December 2015).

BREVES-RAMOS A, JUNQUEIRA AOR, LAVRADO HP, SILVA SHG AND FERREIRA-SILVA MAG. 2010a Population structure of the invasive bivalve Isognomon bicolor on rocky shores of Rio de Janeiro state (Brasil). J Mar Biol Assoc UK 90(3): 453-458.

BREVES-RAMOS A, PIMENTA AD, SZÉCHY MTM AND JUNQUEIRA AOR. 2010b. Mollusca, Bivalvia, 
Mytilidae, Myoforceps aristatus (Dillwyn, 1817): distribution and new record localities at Ilha Grande Bay, Brazil. Check List 6(3): 408-409.

BREVES A AND SKINNER LF. 2014. First record of the vermetid Petaloconchus varians (d'Orbigny, 1841) on floating marine debris at Ilha Grande, Rio de Janeiro, Brazil. J Integ Coast Zone Manag 14(1): 159-161.

BURROWS MT, HARVEY R AND ROBBL L. 2008. Wave exposure indices from digital coastlines and the prediction of rocky shores community structure. Mar Ecol Prog Ser 353: 1-12.

CALVOM, TEMPLADO JAND PENCHASZADEHPE. 1998. Reproductive biology of the gregarious Mediterranean vermetid gastropod Dendrompoma petraeum. J. Mar. Biol. Assoc. UK 78: 525-549.

CHEMELLO R AND SILENZI S. 2011. Vermetid reefs in Mediterranean Sea as archives of sea-level and surface temperatures changes. Chem Ecol 27(2): 121-127.

COCITO S. 2004. Bioconstruction and biodiversity: their mutual influence. Sci Mar 68(1): 137-144.

COLOMBO F, COSTA V, DUBOIS F, GIANGUZZA P, MAZZOLA A AND VIZZINI S. 2013. Trophic structure of vermetid reef community: High trophic diversity at small spatial scales. J Sea Res 77: 93-99.

COSTA HR. 1962. Note preliminaire sur les peuplements intercotidaux de substrat dur du littoral de Rio de Janeiro. Rec Trav St Mar Endoume 27(42): 197-206.

CREED JC, PIRES DC AND FIGUEIREDO MA. 2007. Biodiversidade marinha da Baía da Ilha Grande. Brasília, Distrito Federal: Ministério do Meio Ambiente, 416 p.

DARWIN C. 1841. On a remarkable bar of sandstone off Pernambuco, on the coast of Brazil. Lond Edinb Dub Phil Mag J Sc 19(ser 3): 257-260.

DI FRANCO A, GRAZIANO M, FRANZITTA G, FELLINE S, CHEMELLO R AND MILAZZO M. 2011. Do small marinas drive habitat specific impacts? A case study from Mediterranean Sea. Mar Pollut Bull 62: 926-933.

ESTON VR, MIGOTTO E, OLIVEIRA FILHO EC, RODRIGUES AS AND FREITAS JC. 1986. Vertical distribution of benthic marine organisms on rocky coasts of the Fernando de Noronha Archipelago (Brazil). Bol Inst Oceanogr 34: 37-53.

FRANZITTA G, CAPRUZZI E, LA MARCA EC, MILAZZO M AND CHEMELLO R. 2016. Recruitment patterns in an intertidal species with low dispersal ability: the reefbuilding Dendropoma cristatum (Biondi, 1859) (Mollusca: Gastropoda). Ital J Zool 83(3): 400-407.

GHERARDI DFM AND BOSENCE DWJ. 2001. Composition and community structure of the coralline algal reefs from Atol das Rocas, South Atlantic, Brazil. Coral Reefs 19: 205-219.

HAAS F. 1953. Mollusks from Ilha Grande, Rio de Janeiro, Brazil. Fieldiana (Zool) 34(20): 203-209.
HUGHES RN. 1979. Coloniality in Vermetidae (Gastropoda). In: Larwood G and Rosen BR (Eds), Biology and systematics of colonial animals, Academic Press. London, p. 243-254.

IGNACIO BL, JULIO LM, JUNQUEIRA AOR AND FERREIRA-SILVA MAG. 2010. Bioinvasion in a Brazilian Bay: Filling Gaps in the Knowledge of Southwestern Atlantic Biota. PLoS ONE 5(9): e13065.

IGNACIO BL, LÓPEZ MS AND SILVA JSV. 2012. Colonization plasticity of the boring bivalve Lithophaga aristata (Dillwyn, 1817) on the Southeastern Brazilian coast: considerations on its invasiveness potential. Aquatic Invasion 7(4): 475-482.

KEEN AM. 1961. A proposed reclassification of the gastropod family Vermetidae. Bull Br Mus Nat Hist (Zool) 7: 183213.

KELLY III WC. 2007. Three new vermetid gastropod species from Guam. Micronesica 39(2): 117-140.

LABOREL J. 1977. Are reef-building vermetids disappearing in the South Atlantic? In: CORAL REEF SYMPOSIUM, 1. Proceedings of the Third International Coral Reef Symposium. Rosenstiel School of Marine and Atmospheric Science. D.L. Taylor, p. 233-238.

LABOREL J AND KEMPF M. 1965. Formações de vermetos e algas calcarias nas costas do Brasil. Trab Inst Oceanogr UFPE 7/8: 33-50.

LEAL JH. 1991. Marine prosobranch gastropods from oceanic islands off Brazil: species composition and biogeography. Universal Book Services: Oegstgeest. The Netherlands, $418 \mathrm{p}$.

LIPKIN Y AND SAFRIEL U. 1971. Intertidal zonation of rocky shores at Mikhmoret (Mediterranean, Israel). J Ecol 59: 1-30.

MATTHEWS HR AND KEMPF M. 1970. Moluscos marinhos do norte e nordeste do Brasil. II - Moluscos do Arquipélago de Fernando de Noronha (com algumas referências ao Atol das Rocas). Arq Ciênc Mar 10: 1-53.

MILAZZO M, RODOLFO-METALPA R, CHAN VBC, FINE M, ALESSI C, THIYAGARAJAN V, HALL-SPENCER JM AND CHEMELLO R. 2014. Ocean acidification impairs vermetid reef recruitment. Sci Rep 4: 4189.

MOYSÉS DN, JUNQUEIRA AOR, LAVRADO HP AND SILVA SHG. 2007. Method for monitoring intertidal communities in a steep rocky shore: a combination of digital image technology and field operational strategy. Braz J Oceanogr 55 (1): 19-27.

NONATO E AND PÉRÈS JM. 1961. Observations sur quelques peuplements intertidaux de substrat dur dans la region d'Ubatuba (État de São Paulo). Cah Biol Mar 2: 263-270.

OLIVEIRA FILHO EC AND MAYAL EM. 1976. Seasonal distribution of intertidal organisms at Ubatuba, São Paulo (Brazil). Braz J Biol 36(2): 305-316. 
ORBIGNY A. 1841. Voyage dans l'Amérique Méridionale: les Bresil, la République Orientale de l'Uruguay, la République Argentine, la Patagonie, la République du Chili, la République de Bolivia, la République du Pérou. $3^{\mathrm{a}}$ partie (Mollusques). Paris 5, $456 \mathrm{p}$.

SAFRIEL UN. 1974. Vermetid Gastropods and Intertidal Reefs in Israel and Bermuda. Science 186: 1113-1115.

SAVAZZI E. 1996. Adaptations of Vermetid and Siliquarid Gastropods. Paleontology 39(1): 157-177.

SCHIAPARELLI S AND CATTANEO-VIETTI R. 1999. Functional morphology of vermetid feeding-tubes. Lethaia 32: 41-46.

SCHIAPARELLI S, GUIDETTIPAND CATTANEO-VIETTI R. 2003. Can mineralogical features affect the distribution patterns of sessile gastropods? the Vermetidae case in the Mediterranean Sea. J Mar Biol Assoc UK 83: 1267-1268.

SILENZI S, ANTONIOLI F AND CHEMELLO R. 2004. A new marker for sea surface temperature trend during the last centuries in temperate sites: vermetid reef. Glob Planet Change 40: 105-114.

SILVA SHG, JUNQUEIRA AOR, SILVA MJM, ZALMON IR AND LAVRADO HP. 1989. Fouling and wood-boring communities distribution on the coast of Rio de Janeiro, Brazil. In: Neves C AND Magoon OT (Eds), Coastlines of Brazil. New York: American Society of Civil Engenier, p. 95-109.

SOARES MO, MEIRELLES CAO AND LEMOS VB. 2010. Spatial distribution of vermetids (Mollusca: Gastropoda) in the Rocas Atoll. Bol Mus Para Emílio Goeldi (Ciênc Nat) 5(2): 225-231.

SOARES MO, MEIRELLES CAO AND LEMOS VB. 2011. Reef bioconstructors of the Rocas Atoll, Equatorial. Biotemas 24(2): 37-46.

SOARES-GOMES A, VILLAÇA R AND PEZZELLA CAA. 2001. Atol das Rocas: ecossistema único no Atlântico Sul. Ciência Hoje 29 (172): 32-39.
SPOTORNO PO. 2007. Descrição e zonação de Vermetídeos (Mollusca: Vermetidae) do Arquipélago de São Pedro e São Paulo, Brasil. Master Thesis, Fundação Universidade do Rio Grande. Programa de Pós-Graduação em Oceanografia Biológica, 2007, 81 p. (Unpublished).

SPOTORNO P, Tâmega FTS and Bemvenuti CE. 2012. An overview of the recent vermetids (Gastropoda: Vermetidae) from Brazil. Strombus 19(1): 1-8.

STRATHMANN MF and Strathmann R. 2006. A vermetid gastropod with complex intracapsular cannibalism of nurse eggs and sibling larvae and a high potential for invasion. Pac Sci 60(1): 97-108.

STRONG EE. 2003. Refining molluscan characters: morphology, character coding and a phylogeny of the Caenogastropoda. Zool J Linn Soc 137: 447-554.

TEIXEIRA TP, NEVES LM AND ARAÚJO FG. 2009. Effects of a nuclear power plant thermal discharge on habitat complexity and fish community structure in Ilha Grande Bay, Brazil. Mar Envir Res 68: 188-195.

THOMAS MLH. 1986. A physically derived exposure index for marine shorelines. Ophelia 25(1): 1-13.

VESCOGNI A, BOSELLINI FR, REUTER M AND BRACHERT TC. 2008. Vermetid reefs and their use as palaeobathymetric markers: new insights from the late Miocene of the Mediterranean (Southern Italy, Crete). Palaeogr Palaeoclimatol Palaeoecol 267: 89-101.

VILLAÇA R. 2009. Recifes Biológicos. In: Pereira RC and Soares-Gomes A (Eds), Biologia Marinha. $2^{\text {a }}$ ed., Rio de Janeiro. Editora Interciência, p. 399-420.

VILLAÇA R AND PITOMBO FB. 1997. Benthic communities of shallow-water reefs of Abrolhos, Brazil. Braz J Oceanogr 45(1/2): 35-43.

WEINBERGER VP, MILOSLAVICH PAND MACHORDOM P. 2010. Distribution pattern, reproductive traits, and molecular analysis of two coexisting vermetid gastropods of the genus Petaloconchus: a caribbean endemic and a potential invasive species. Mar Biol 157: 1625-1639. 